\title{
Estimation of the physicochemical variation of chickpea seeds (Cicer arietinum $\mathbf{L}$.)
}

\author{
Wojciech Rybiński ${ }^{1}$,Maciej Banda ${ }^{2}$, Jan Bocianowski ${ }^{3}{ }^{-1}$, Elżbieta Starzycka-Korbas ${ }^{4}$, Michat Starzycki ${ }^{4}$, \\ and Kamila Nowosad ${ }^{5}$ (D) \\ ${ }^{1}$ Institute of Plant Genetics, Polish Academy of Sciences, Strzeszyńska 34, 60-479 Poznań, Poland \\ ${ }^{2}$ Institute of Agrophysics, Polish Academy of Sciences, Doświadczalna 4, 20-290 Lublin, Poland \\ ${ }^{3}$ Department of Mathematical and Statistical Methods, Poznań University of Life Sciences, Wojska Polskiego 28, \\ 60-637 Poznań, Poland \\ ${ }^{4}$ Institute of Plant Breeding and Acclimatization, Department of Oil Plants, Strzeszyńska 36, 60-479 Poznań, Poland \\ ${ }^{5}$ Department of Genetics, Plant Breeding and Seed Production, Wrocław University of Environmental and Life Sciences, \\ Grunwaldzki 24A, 53-363 Wrocław, Poland
}

Received February 23, 2018; accepted November 4, 2018

\begin{abstract}
An attempt was made to assess the reaction of seeds to mechanical loads, taking into account their geometry expressed as seed thickness and 100 seed weight. The research material comprised the collection material of chickpeas representing various geographical regions in the world. Generally, the small-seeded accessions expressed by 100 seed weight were characteristic of the Desi type, with the lowest values of 12.3 and $14.6 \mathrm{~g}$, respectively, concerning the seeds originating in Ethiopia and India, and the highest value (26.6 g) for the accession derived from Turkey. The large-seeded accessions were typical of the Kabuli type, with the highest value of 100 seed weight above 50 $\mathrm{g}$ obtained for the accession derived from Czech Republic. The obtained results allowed for selecting the chickpea accessions displaying a high resistance of seeds to static loading, from among both the Kabuli and Desi plant types. The average protein contents for the Kabuli and Desi seed types were on the same level (14.6\%), ranging for all the accessions under analysis from $11.8 \%$ to $18.4 \%$. The fat values ranged from $6.4 \%$ for Desi type No. 44 originating in Ethiopia, to $13.7 \%$ for Kabuli type No. 26 of Turkish origin, and the average content was slightly higher in the Kabuli seed type (8.73\%) than in the Desi seed type (7.89\%).

Key w ord s: chickpea, seed thickness, static loading of seeds, protein, fatty acids
\end{abstract}

\section{INTRODUCTION}

Food legumes, comprising dry bean, dry pea, soybean, groundnut, chickpea, pigeon pea, lentil, mung bean, lathyrus and cowpea, have a considerable global area under cultivation. In terms of agricultural importance, food leg-

*Corresponding author e-mail: jan.bocianowski@up.poznan.pl umes, after cereals, represent the most valued food source because of their significance for both humans and animals, as well as the soil ameliorative values, and the ability to thrive under harsh and fragile environmental conditions. Chickpea (Cicer arietinum L.) is one of the most important members of above mentioned species. Chickpea, also called garbanzo bean or Bengal gram, is one of the Old World species and a member of the West Asian Neolithic crop assemblage, associated with the origin of agriculture in the Fertile Crescent about 10000 years ago. It most probably originated in the area of present-day south-eastern Turkey, i.e. the region adjoining Syria (Abbo et al., 2003). Chickpea is the second most important pulse crop, after dry bean, being a major source of human food and animal feed. It is traditionally grown in many parts of the world and, like other pulse crops, chickpea has multiple functions in the traditional farming system in many developing countries. It is particularly valuable for people who do not consume enough animal products (Yucel et al., 2006). Chickpea is the third most important grain legume in the world, and the first in South Asia, when it comes to both the cultivation area and production. Currently, chickpea is grown in over fifty countries across the above-mentioned Indian subcontinent, as well as in North Africa, the Middle East, Southern Europe, the Americas and Australia (Jukanti et al., 2012). In global terms, chickpea was grown on 14.58 million ha in 2014, as compared to 10.14 million ha in 2000. In EU 
countries, with the dominant position being occupied by field pea (520 thousand ha), the area under chickpea cultivation was very small, amounting to 40.5 thousand ha in 2014. In 2000, the global chickpea production was at the level of 8 million $t$, and in 2014 the chickpea seed production increased to 14.24 million $\mathrm{t}$, as compared to 45.41 thousand $\mathrm{t}$ in EU countries. Between 2000 and 2014, the average yield increased from 789 to $1378 \mathrm{~kg} \mathrm{ha}^{-1}$. India is the largest chickpea producer (Jukanti et al., 2012). In this country, chickpea is the premier pulse crop grown on an area of about 8.25 million ha, with a production volume of 7.05 million tonnes (and with an average productivity of $620 \mathrm{~kg}$ $\mathrm{ha}^{-1}$ ), which accounts for $75 \%$ of the world's chickpea production (Ramanappa et al., 2013). In Pakistan, chickpea is grown on an area of 1.081 million ha, with a productivity of 0.741 million tons (Akhtar et al., 2011). The other major chickpea-producing countries include Turkey, Australia, Myanmar, Ethiopia, Mexico, Canada and the USA.

However, chickpea is an important pulse crop, currently ranking second in terms of the cultivation area, and third in terms of production. As regards the future production, a new chickpea crop improvement programme appears necessary. Similar to other grain legumes (Rybiński et al., 2015), the progress in chickpea cultivation, in terms of grain yield and yield-quality improvement, included an increase in the protein content (with an enhanced amino acids composition), a reduction in the content of anti-nutritive components, and a limitation of the plants' susceptibility to lodging and abiotic stresses (drought, diseases and pest). These should relate to the ultimate goal of the grower to make chickpea more competitive, as compared to other main species of grain legumes. Other traits are also important but they are often disregarded by growers due to the lack of necessary equipment or, in many cases, insufficient experience. These traits include the mechanical properties of seeds. The mechanical properties of seeds are an element that is underestimated and still little known. The knowledge of the physical parameters of seeds has a particular importance for the harvest, drying and storage optimisation technologies, which are related to the minimisation of quantitative losses and mechanical damage caused, inter alia, by a decreased seeds germination ability (Rybiński et al., 2015). The biological values of seeds, which are characterised, inter alia, by their germination capacity, are determined by a number of external factors, beginning with the time of seed ripening under field conditions and ending with the effect of the forces acting in a harvester threshing assembly, seed cleaning devices, sorting and drying equipment, as well as transport and storage. The technological processes listed above have an effect on the physical status of seeds, which leads to the diversification of their resistance to mechanical loads. The micro- and macro-damage originating from those processes may have a negative impact on both seed quality and yield. The variability of the physical properties of seeds depends on a great variety of external factors, as well as on the species- and cultivar-related traits, often connected with genetic background. Expression of these traits depends on different factors which manifest themselves both during the growth and development of plants in the field, and after harvest. Literature reports the occurrence of notable inter-variety differences in seed resistance to mechanical deformation, even at identical geometric seed parameters. This creates a possibility of suitably selecting the components for cross-cultivation and directed cultivation. The knowledge of specific reactions of cultivars or new breeding lines, in relation to the broadly-perceived physical properties of seeds, could constitute a valuable source of information for growers. A very important source of variability of many traits, including mechanical properties (connected, inter alia, with the chemical composition of seeds), is provided by the accessions stored in Gene Banks, representing chickpea genotypes of different geographical origins. This paper is an attempt at determining the resistance of seeds to mechanical loads and their chemical composition using the chickpea accessions obtained from Gene Banks, representing European countries as well as other geographical regions in the world.

\section{MATERIALS AND METHODS}

The research material comprised seeds of 48 of chickpea accessions derived from an independent collection, as well as from the Gene Bank in Gatersleben (Germany) and RICP Prague-Ruzyne (Czech Republic). Some of the accessions (Table 1) constituted chickpea of the Kabuli type, characterised by white flowers and white or beige-coloured seeds, with a thin seed coat. The remaining accessions belonged to the Desi type, having pink or deep-red flowers, and a coloured (brown or dark-brown) and thick seed coat. As shown in Table 1, among all the analysed accessions (numbered 1 to 48), forty three constituted accessions of European origin (Poland, No. 1; Russia, Nos 2-6; Slovakia, Nos 7-11; Czech Republic, Nos 12-15; Albania, Nos 16-20; Bulgaria, Nos 21-24; Turkey, Nos 25-29; Greece, Nos 30-34; Italy, Nos 35-39; Portugal, Nos 40-41; Spain, No. 42; and England, No. 43), and five were derived from Ethiopia (No. 44), Morocco (No. 45), Australia (No. 46), India (No. 47) and Cuba (No. 48).

The collected seeds were analysed in terms of their physical properties. For 100 seeds weight estimation (five replications $\times 100$ seeds), an electronic seed counter was used. The determination of geometric measurements included seed thickness. This parameter was measured using an adapted dial gauge and an electronic slide calliper with an accuracy of $0.01 \mathrm{~mm}$. To obtain a detailed distribution of this property in air-dry seed samples, 30 replications were made on the same seeds that were selected at random.

The resistance of individual seeds to static loading was determined using strength installation - Lloyd LRX and the Nexygen programme for measurement recording and 
Table 1. Origin, phenotypic traits and 100 seed weight of chickpea accessions (Cicer arietinum L.)

\begin{tabular}{|c|c|c|c|c|c|c|c|}
\hline No. & $\begin{array}{c}\text { Accession } \\
\text { code (CAR } \\
- \text { Cicer } \\
\text { arietinum } \mathrm{L} .\end{array}$ & $\begin{array}{c}\text { Accession } \\
\text { number of } \\
\text { donors }^{1}\end{array}$ & $\begin{array}{c}\text { Country of } \\
\text { origin }\end{array}$ & Plant type & $\mathrm{FC}^{2}$ & $\mathrm{SCC}$ & $100 \mathrm{SW}(\mathrm{g})$ \\
\hline 1 & CAR 18 & $\mathrm{DZ} 1$ & Poland & Kabuli & White & Beige (white) & 23.65 \\
\hline 2 & CAR 46 & CIC 65 & Russia & Kabuli & White & Beige & 22.89 \\
\hline 3 & CAR 47 & CIC 66 & Russia & Kabuli & White & Beige & 18.20 \\
\hline 4 & CAR 58 & CIC 58 & Russia & Desi & Deep-red & Dark brown & 22.95 \\
\hline 5 & CAR 59 & CIC 46 & Russia & Kabuli & White & Beige & 27.20 \\
\hline 6 & CAR 60 & CIC 48 & Russia & Kabuli & White & Beige & 29.83 \\
\hline 7 & CAR 48 & CIC 77 & Slovakia & Kabuli & White & White-creme & 23.91 \\
\hline 8 & CAR 49 & CIC 78 & Slovakia & Kabuli & White & Beige & 25.25 \\
\hline 9 & CAR 50 & CIC 79 & Slovakia & Kabuli & White & Beige & 23.13 \\
\hline 10 & CAR 51 & CIC 80 & Slovakia & Kabuli & White & Beige & 22.11 \\
\hline 11 & CAR 52 & CIC 81 & Slovakia & Kabuli & White & Beige & 21.57 \\
\hline 12 & CAR 29 & CIC 68 & Czech & Kabuli & White & Beige & 25.85 \\
\hline 13 & CAR 30 & CIC 86 & Czech & Kabuli & White & Beige & 22.04 \\
\hline 14 & CAR 68 & L11 00031 & Czech & Kabuli & White & White-creme & 51.41 \\
\hline 15 & CAR 65 & L11 IR 2 & Czech & Desi & Pink & Brown & 20.77 \\
\hline 16 & CAR 19 & CIC 209 & Albania & Kabuli & White & Beige & 28.70 \\
\hline 17 & CAR 20 & CIC 210 & Albania & Kabuli & White & Beige & 38.55 \\
\hline 18 & CAR 21 & CIC 214 & Albania & Desi & Pink & Brown & 22.92 \\
\hline 19 & CAR 22 & CIC 231 & Albania & Kabuli & White & Creme & 22.71 \\
\hline 20 & CAR 23 & CIC 235 & Albania & Desi & Pink & Brown & 24.27 \\
\hline 21 & CAR 24 & CIC 233 & Bulgaria & Kabuli & White & Beige & 43.50 \\
\hline 22 & CAR 25 & CIC 729 & Bulgaria & Kabuli & White & Beige & 43.64 \\
\hline 23 & CAR 26 & CIC 754 & Bulgaria & Kabuli & White & Beige & 43.16 \\
\hline 24 & CAR 27 & CIC 755 & Bulgaria & Kabuli & White & Beige & 36.49 \\
\hline 25 & CAR 15 & LM 1 & Turkey & Kabuli & White & Beige & 22.47 \\
\hline 26 & CAR 16 & LM 2 & Turkey & Kabuli & White & Beige & 27.90 \\
\hline 27 & CAR 80 & CIC 3 & Turkey & Kabuli & White & Beige & 20.23 \\
\hline 28 & CAR 81 & CIC 5 & Turkey & Kabuli & White & Beige & 25.96 \\
\hline 29 & CAR 82 & CIC 8 & Turkey & Desi & Pink & Brown & 26.56 \\
\hline 30 & CAR 34 & CIC 10 & Greece & Kabuli & White & Beige & 17.78 \\
\hline 31 & CAR 35 & CIC 11 & Greece & Kabuli & White & White-creme & 18.86 \\
\hline 32 & CAR 36 & CIC 19 & Greece & Kabuli & White & Creme & 23.33 \\
\hline
\end{tabular}


Table 1. Continuation

\begin{tabular}{|c|c|c|c|c|c|c|c|}
\hline No. & $\begin{array}{c}\text { Accession } \\
\text { code }(\mathrm{CAR} \\
- \text { Cicer } \\
\text { arietinum L. }\end{array}$ & $\begin{array}{l}\text { Accession } \\
\text { number of } \\
\text { donors }^{1}\end{array}$ & $\begin{array}{c}\text { Country of } \\
\text { origin }\end{array}$ & Plant type & $\mathrm{FC}^{2}$ & $\mathrm{SCC}$ & $100 \mathrm{SW}(\mathrm{g})$ \\
\hline 33 & CAR 37 & CIC 23 & Greece & Desi & Deep-red & Dark brown & 16.31 \\
\hline 34 & CAR 38 & CIC 29 & Greece & Desi & Pink & Brown & 16.76 \\
\hline 35 & CAR 53 & CIC 100 & Italy & Kabuli & White & White & 31.80 \\
\hline 36 & CAR 54 & CIC 101 & Italy & Kabuli & White & Beige (white) & 30.74 \\
\hline 37 & CAR 55 & CIC 106 & Italy & Kabuli & White & Beige & 40.89 \\
\hline 38 & CAR 56 & CIC 113 & Italy & Kabuli & White & Beige & 31.7 \\
\hline 39 & CAR 57 & CIC 230 & Italy & Kabuli & White & Beige & 41.54 \\
\hline 40 & CAR 45 & CIC 722 & Portugal & Kabuli & White & Beige & 48.19 \\
\hline 41 & CAR 69 & L 1110061 & Portugal & Kabuli & White & Beige (white) & 43.53 \\
\hline 42 & CAR 39 & CIC 736 & Spain & Kabuli & White & Beige-creme & 25.05 \\
\hline 43 & CAR 70 & L 1100008 & England & Kabuli & White & Beige & 23.25 \\
\hline 44 & CAR 31 & CIC 57 & Ethiopia & Desi & Pink & Brown & 12.29 \\
\hline 45 & CAR 86 & CIC 525 & Marocco & Desi & Pink & Brown & 26.23 \\
\hline 46 & CAR 67 & L11 00037 & Australia & Desi & Pink & Brown & 18.30 \\
\hline 47 & CAR 43 & CIC 517 & India & Desi & Pink & Brown & 14.62 \\
\hline 48 & CAR 113 & CIC 177 & Cuba & Kabuli & White & Beige (white) & 38.80 \\
\hline $\begin{array}{l}\text { Mean - type } \\
\text { Kabuli }\end{array}$ & & & & & & & 29.9 \\
\hline $\begin{array}{l}\text { Mean - type } \\
\text { Desi }\end{array}$ & & & & & & & 20.2 \\
\hline
\end{tabular}

${ }^{1}$ Donors of accessions: CIC - Gene Bank Gatersleben; L11 - Gene Bank RICP Prague-Ruzyne; DZ - Gene Bank Poznań, Poland; LM 1 and LM 2 - seeds received from local food market in Poland, ${ }^{2}$ FC - flower colour; SCC - seed coat colour; 100 SW - 100 seed weight.

the calculation of mechanical parameters. The basic test of seed resistance to compression was performed using the following parameters: the reading head of $2.5 \mathrm{kN}$, the head motion speed of $5 \mathrm{~mm} /$ minute and the compression depth of $1.5 \mathrm{~mm}$. The measurement recording process started when the strength exceeded $0.5 \mathrm{~N}$. The results of the parameter determination were expressed in the following values: the maximum load $(\mathrm{N})$ - the compressive force causing seed failure; deflection at the max. load $(\mathrm{mm})$ - the maximum seed deformation at the moment of failure; stress at the max. load $(\mathrm{MPa})$ - stress intensity at the moment of seed failure, and work to the max. load $(\mathrm{J})$ - the energy required for seed crushing.

The harvested seeds of all the objects were used for estimations of the protein and fat content, as well as the fatty acids composition. The protein content was examined by means of the Kjeldahl method. The Soxhlet analysis was performed in order to quantify seed oil. Inside the thimble, made of thick paper, particulate material was placed ( $10 \mathrm{~g}$ of seed), and then extracted $12 \mathrm{~h}$ in a Soxhlet extractor with n-hexane. The samples were weighed after extraction, and the loss of fat was determined in terms of percentage share. The composition of fatty acids was determined (GC) using a Hewlett Packard gas chromatograph, Agillent Technologies 6890N Network GC System. Fat extraction and esterification of the methyl esters of fatty acids, as well as quantitative estimates of chromatograms were performed. The methyl esters of fatty acids were separated using a DB-23 capillary column. Hydrogen was used for the purpose of carrier gas GC analysis. The temperature of the chromatography column was $200^{\circ} \mathrm{C}$ and that of the detector $220^{\circ} \mathrm{C}$. The chromatographic separation of the 
analysed compounds lasted $10 \mathrm{~min}$. The Chemistation programme was used to calculate the percentage share of each fatty acid. By means of a chromatograph, the following fatty acids were estimated: palmitic $\left(\mathrm{C}_{16: 0}\right)$, stearic $\left(\mathrm{C}_{18: 0}\right)$, oleic $\left(\mathrm{C}_{18: 1}\right)$, linoleic $\left(\mathrm{C}_{18: 2}\right)$ and linolenic $\left(\mathrm{C}_{18: 3}\right)$.

The normality of the distribution of the traits was tested with the Shapiro-Wilk's normality test (Shapiro and Wilk, 1965). The one-way fixed model analysis of variance (ANOVA) was carried out to determine the effect of the analysed accessions on the variability of the observed traits. Estimations were also made using mean values, maximum and minimum values, and the coefficient of variation (Kozak et al., 2013) for the studied traits. The positions characteristic of every accession, in terms of seed thickness, the maximum load, deflection at the maximum load, stress at the maximum load and work to the maximum load, were presented in the form of boxplots. The relationships between all the traits were estimated on the basis of correlation coefficients. The analysis of canonical varieties made it possible to develop a graphic distribution of accessions, described by the maximum load, deflation at the maximum load, stress at the maximum load and work to the maximum load, . The graphic distribution of accessions, described by means of the chemical composition of all the seeds combined, was obtained by means of the principal components analysis (PCA). All analyses were done in GenStat 18.

\section{RESULTS AND DISCUSSION}

An effective strategy to minimise genetic vulnerability involves using a genetically different plants material from the collection of diverse geographic origins. Such material was used in the performed investigation (Table 1). There are two distinct types of cultivated chickpea: Desi and Kabuli. The Kabuli (macrosperma) types are characterized by white flowers and the lack of anthocyanin pigmentation on the stem, and they have white or beige-coloured seeds with a smooth seed surface and a thin seed coat. The Desi (microsperma) types have a pink or deep-red flowers, anthocyanin pigmentation on the stem, and a coloured (brown or dark-brown) and thick seed coat (Table 1). The Desi type seeds account for about $80-85 \%$ of the total chickpea cultivation area, and are mostly grown in Asia and Africa. The Kabuli accessions are mostly of European origin but they are also largely grown in West Asia, North Africa and North America (Jukanti et al., 2012). Generally, the small-seeded accessions expressed by 100 seed weight were characteristic of the Desi type, with the lowest values of 12.3 and $14.6 \mathrm{~g}$, respectively, being recorded for accessions CAR 31 and 43, originating in Ethiopia and India, and highest $(26.6 \mathrm{~g})$ for CAR 82 derived from Turkey. The large-seeded accessions were typical of the Kabuli type, with the highest value of 100 seed weight above $50 \mathrm{~g}$ recorded for accession CAR 68 from Czech Republic. For other seven accessions, the weight of 100 seeds exceeded $40 \mathrm{~g}$ (Table 1). The screening of more than 16000 accessions obtained from the global collection revealed a wide range of seed sizes (4-63 g of 100 seed weight) (Upadhyaya, 2003), and the results obtained through screening 179 genotypes ranged from 9.0 to $30 \mathrm{~g}$ (Ramanappa et al., 2013). For forty, fifteen and two Kabuli genotypes, the 100 seed weight values ranged from 33.5 to $42.5 \mathrm{~g}$, from 28.1 to $56.6 \mathrm{~g}$, and from 30.7 to $33.0 \mathrm{~g}$, respectively (De Falco et al., 2010), and for the fourteen lines originating in Turkey the average 100 seed weight was $33.7 \mathrm{~g}$ (Yucel et al., 2006).

Estimation of the quality of agricultural material requires the knowledge of the range of variability of its physical, and in particular mechanical, properties expressed, inter alia, by the compressive strength of seeds, with reference to various species of crop plants. Seed damage my occur even prior to harvest, when internal damage is observed, under certain unfavourable environmental conditions, in the course of the seed filling process, especially due a high gradient of moisture in the seed. Mechanical damage my occur at any seed treatment stage, beginning with harvest (cracking or breaking of seed fragments), through transport and storage, up to final processing (grinding). The results of the analysis of variance revealed that the parameters of the mechanical loading of seeds and seed thickness for the accessions under estimation differed significantly with respect to each feature at the level of 0.001 , and the calculated coefficient of variation for mechanical loading was higher as compared to seed thickness (Table 2). This finding was supported by the characteristics of the variable expressed by mean values. Some of them indicated seed thickness and four parameters of mechanical loading, and were expressed graphically in the form of boxplots for each of the accessions presented in Fig. 1. Prior to the estimation of seed resistance to static loads, geometric properties were determined and expressed as seed thickness (Fig. 1a). In terms of the type of the analysed chickpea accessions, the average value was $6.73 \mathrm{~mm}$ for the Kabuli type and 5.98 for the Desi type. Among the Kabuli accessions, the highest seed thickness value $(8.31 \mathrm{~mm})$ was obtained for accession No. 14 (CAR 68) originating in Czech Republic, and the lowest $(5.61 \mathrm{~mm})$ for accession No. 30 (CAR 34) derived from Greece. The values recorded for the Desi type ranged from $7.16 \mathrm{~mm}$ for No. 29 (CAR 82) derived from Turkey to $5.42 \mathrm{~mm}$ for No. 44 (CAR 31) originating in Ethiopia. No clear-cut link was observed between the seed thickness and geographical origin of the analysed accessions; however, the Desi type was characterised by generally lower seed thickness as compared to the Kabuli type. The chickpea seeds are very variable in size, from 5 to $10 \mathrm{~mm}$ in diameter. Notable differences in the value of seed thickness were revealed by Rybiński et al. (2004) for the grass pea mutant. In terms of seed resistance to mechanical loads, expressed by the maximum load (Fig. 1b), the mean value for all the accessions was $233.7 \mathrm{~N}$, with the coefficient of variation reaching the level of $40.04 \%$. The obtained results indicate 
Table 2. Mean squares from one-way analysis of variance (ANOVA) and coefficient of variability for investigated traits of studied accessions

\begin{tabular}{|c|c|c|c|}
\hline Source of variation & Accessions & Residual & Coefficient of variation $(\%)$ \\
\hline \multicolumn{4}{|c|}{ Maximum load } \\
\hline Number of degrees of freedom & 47 & 96 & 40.04 \\
\hline Mean squares & $17529 * * *$ & 4467 & \\
\hline \multicolumn{4}{|c|}{ Deflection at maximum load } \\
\hline Number of degrees of freedom & 47 & 96 & 39.34 \\
\hline Mean squares & $0.15816^{* * *}$ & 0.04701 & \\
\hline \multicolumn{4}{|c|}{ Stress at maximum load } \\
\hline Number of degrees of freedom & 47 & 96 & 40.04 \\
\hline Mean squares & $11.835 * * *$ & 3.016 & \\
\hline \multicolumn{4}{|c|}{ Work at maximum load } \\
\hline Number of degrees of freedom & 47 & 96 & 73.86 \\
\hline Mean squares & $0.009008 * * *$ & 0.002712 & \\
\hline \multicolumn{4}{|c|}{ Seed thickness } \\
\hline Number of degrees of freedom & 47 & 2441 & 12.06 \\
\hline Mean squares & $35.2419 * * *$ & 0.1705 & \\
\hline
\end{tabular}

a broad variability of this parameter among the accessions under analysis. The highest compressive force causing seed failure $(388.7 \mathrm{~N})$ was used for accession No. 41 (CAR 69 from Portugal) and the lowest $(45.7 \mathrm{~N})$ for accession No. 15 (CAR 65) of Czech origin. What appears characteristic are the very low values of the maximum load for small-seeded Desi accessions Nos 44 and 47, originating in Ethiopia and India. A similar average value of this parameter, at the level of $240 \mathrm{~N}$, was obtained for lentil seeds, while the value of $276 \mathrm{~N}$ was obtained for grass pea seeds, 440 and $404 \mathrm{~N}$ for narrow-leafed and yellow lupine, respectively, and $932 \mathrm{~N}$ for the particularly resistant seeds of white lupine (Rybiński et al., 2014). The same accession as for the maximum load (No. 15 from Czech Republic) also showed the lowest seed deformation at the moment of failure $(0.20 \mathrm{~mm})$, expressed by the second parameter employed in the analysis, i.e. deflection at the maximum load (Fig. 1c). The highest value $(1.57 \mathrm{~mm})$ was recorded for Polish accession No. 1 (CAR 18) as well as for accession No. 21 (1.17 $\mathrm{mm}$ ) from Bulgaria (CAR 24). The mean value of this parameter for all the accessions was $0.74 \mathrm{~mm}$. For barley mutants and cultivars, the value of deflection at the maximum load ranged from 0.27 to $0.47 \mathrm{~mm}$. For the grass pea accessions, it ranged from 0.30 to $0.73 \mathrm{~mm}$ (Rybiński et al., 2008), and for the common vetch from 0.35 to 1.01 mm (Rybiński et al., 2015). Markedly higher values were obtained for the cultivar and lines of white- and narrowleafed lupine, ranging from 1.84 to $3.08 \mathrm{~mm}$, and from 1.85 to $2.67 \mathrm{~mm}$, respectively (Rybiński et al., 2014). The third mechanical loading parameter, expressed as stress at the maximum load (Fig. 1d), provides information about stress intensity at the moment of seed failure. The mean value of this parameter for all the accessions was 6.07 $\mathrm{MPa}$. The broad range of variability was observed for the investigated accessions. Similar to the above two mechanical loading parameters, the lowest value $(1.18 \mathrm{MPa})$ was obtained for accession No. 15 (CAR 65) originating in Czech Republic, and the highest (10.10 MPa) for No. 41 (CAR 69) derived from Portugal. The same accession also showed the lowest and the highest values of the maximum load parameter. The last mechanical loading parameter under analysis (work to the maximum load) provides information about the energy needed for seed crushing (Fig. 1e). The mean value of this parameter for all the accessions under examination was $0.093 \mathrm{~J}$, and it was at the same level $(0.097 \mathrm{~J})$ as for some species of pulse crops (Rybiński et al., 2015). The value of energy needed for seed crushing ranged from $0.0044 \mathrm{~J}$ for Desi accession No. 15 derived from Czech Republic to $0.331 \mathrm{~J}$ for accession No. 18 of the Kabuli type of Polish origin. Apart from accession No. 15, only one accession of the Kabuli type, i.e. No. 41 originating from Portugal and characterised by high seed thickness (Fig. 1a), exceeded the value of $0.2 \mathrm{~J}$. A narrower range of variation, i.e. from $0.025 \mathrm{~J}$ to $0.18 \mathrm{~J}$, was recorded for common vetch accession No. 44, and a very high mean value was characteristic of the white - and narrow-leafed lupine, reaching 


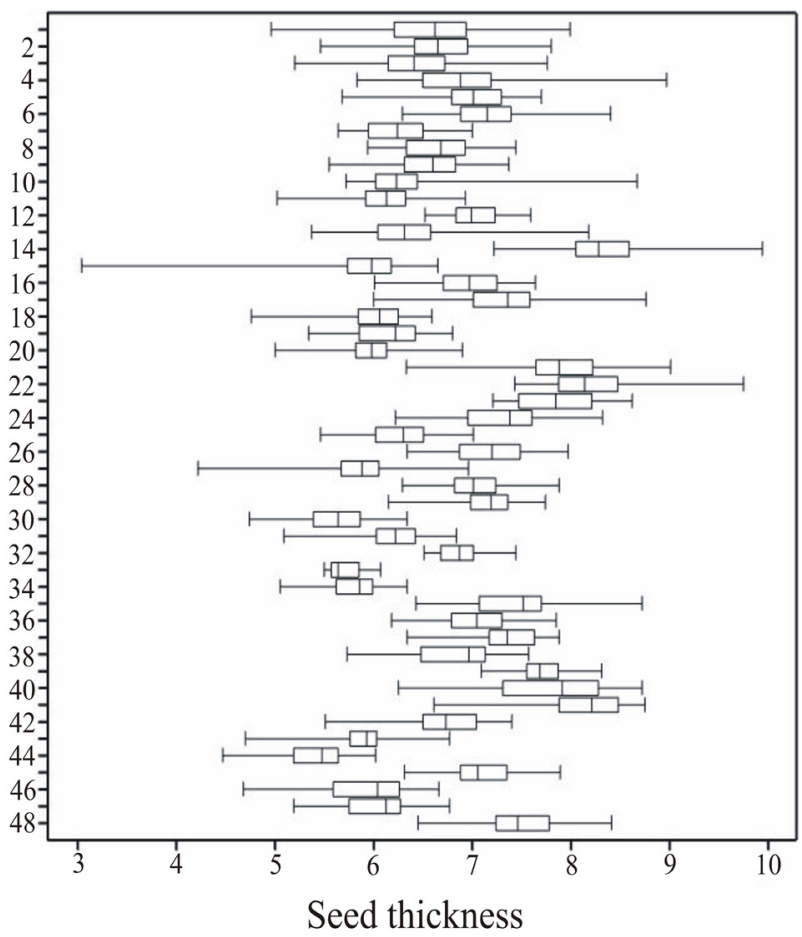

c

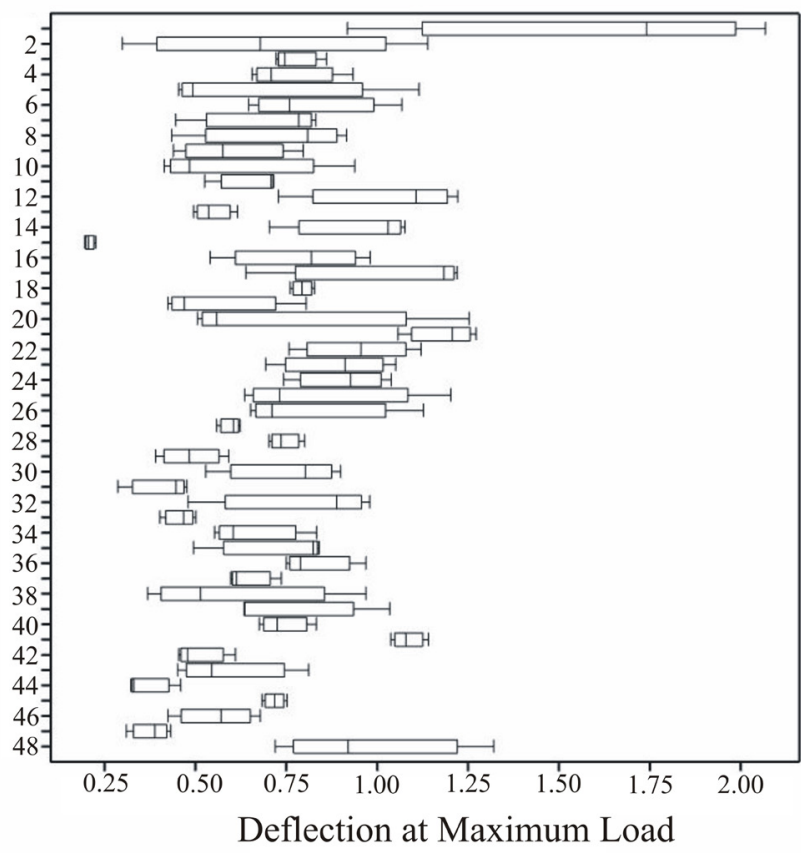

b

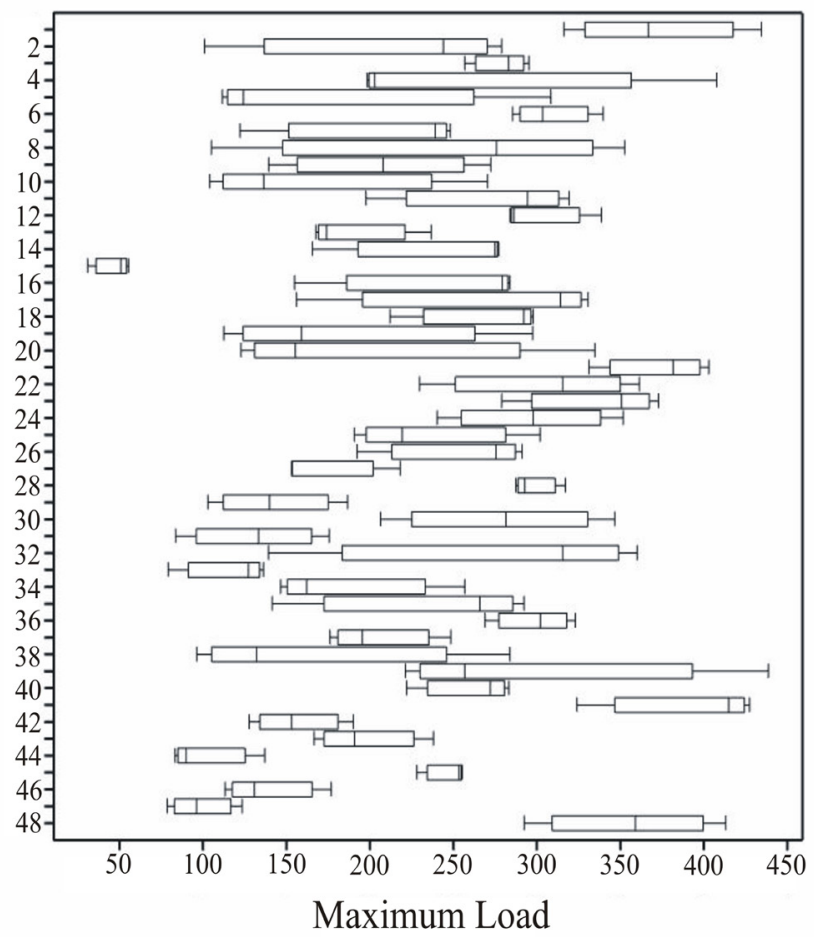

d

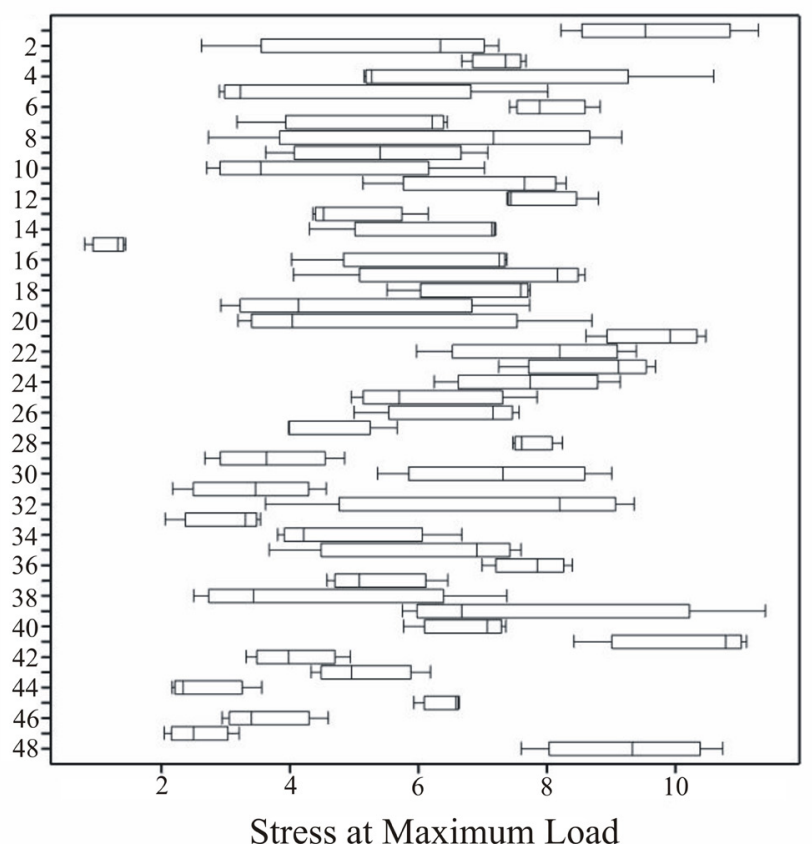

Fig. 1. Box-and-whisker diagram of: $\mathrm{a}$ - seed thickness values $(\mathrm{mm}), \mathrm{b}-$ maximum load values $(\mathrm{N}), \mathrm{c}-$ deflection at the maximum load $(\mathrm{mm}), \mathrm{d}$ - stress at the maximum load (MPa), e - work to the maximum load $(\mathrm{J})$ for the analyses of chickpea accessions $($ Cicer arietinum L.). See the accession number explanations in Table 1. 
e

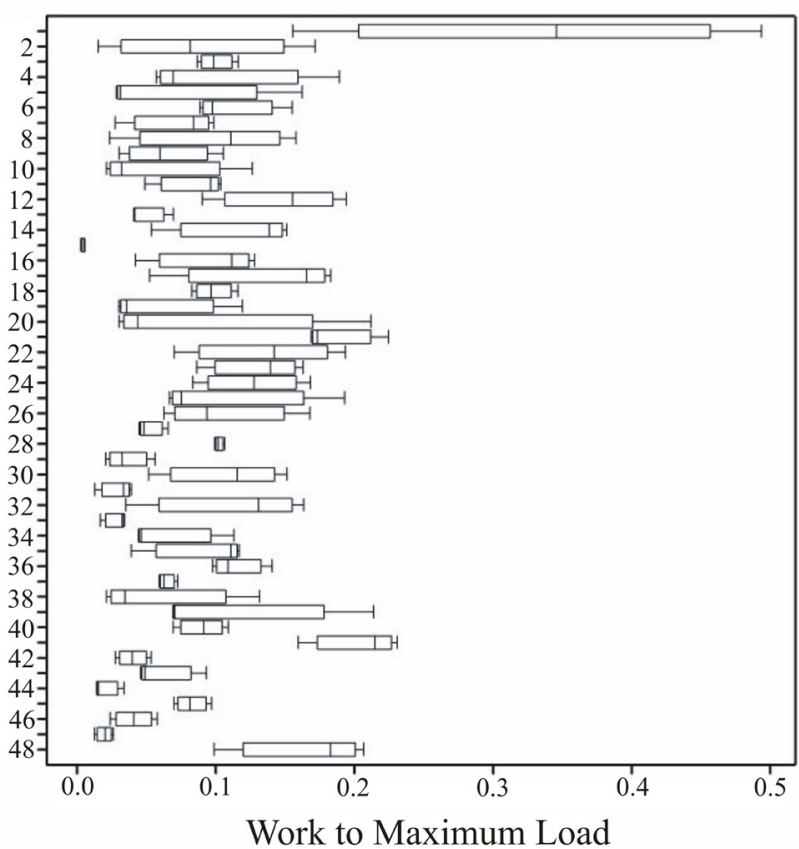

Fig. 1. Continuation.

the level of $0.6 \mathrm{~J}$ (Rybiński et al., 2015). A confirmation of a separate character of the analysed forms is provided by the positioning of the accessions on the plane in a system of the first two canonical variables, in terms of all the analysed traits of mechanical loads (Fig. 2). The most divergent of all the accessions is No. 1 (CAR 18) of Polish origin (the bottom of the space), followed by Desi type No. 15 from Czech Republic (the left part) and Kabuli type No. 41 from
Portugal (the right part), as well as Desi accessions Nos 47 and 44 originating in India and Ethiopia, respectively. With an exception of the above-mentioned accessions, the remaining forms occupied closely the upper part of the plain which indicates a considerable similarity of those forms in terms of their resistance to mechanical loads (Fig. 3).

Chickpea has been consumed by people since ancient times, owing to its good nutritional properties. Furthermore, chickpea is of interest as functional food with the potentially beneficial effects on human health. It is also an important pulse crop all over the world which is known as a good source of carbohydrates and protein, and its protein quality is considered to be better than that of other pulses (Jukanti et al., 2012). The results of biochemical analyses in terms of protein, fat and fatty acids profiles in the seeds of the investigated chickpea accessions are shown in Table 3. In the investigated seeds, the average protein content for the Kabuli as well as Desi types was at this same level $(14.6 \%)$. For all the accessions, the protein content ranged from $11.8 \%$ for Desi type No. 46 (CAR 67) of Australian origin to $18.4 \%$ for Kabuli type No. 40 (CAR 45) derived from Portugal (Table 3). A similar range of the protein content (17.1-19.8\%) was observed by Frimpong et al. (2009), and broader ranges, i.e. $16.4-31.2$ and $18.46-24.46 \%$, by Şehirali (1988) and Nobile et al. (2013), respectively.

The fat (lipid) content of pulse varies among species. Most species contain about $1 \%$ of fat, while groundnut and soybean have 30 and $49 \%$, respectively (FAO, 1968). The oil fraction in chickpea is one of the highest among dry pulse crops, constituting from 3 to $10 \%$ of the total dry seed weight (De Almeida Costa et al., 2006). The fat content variations are shown in Table 3 . The obtained values

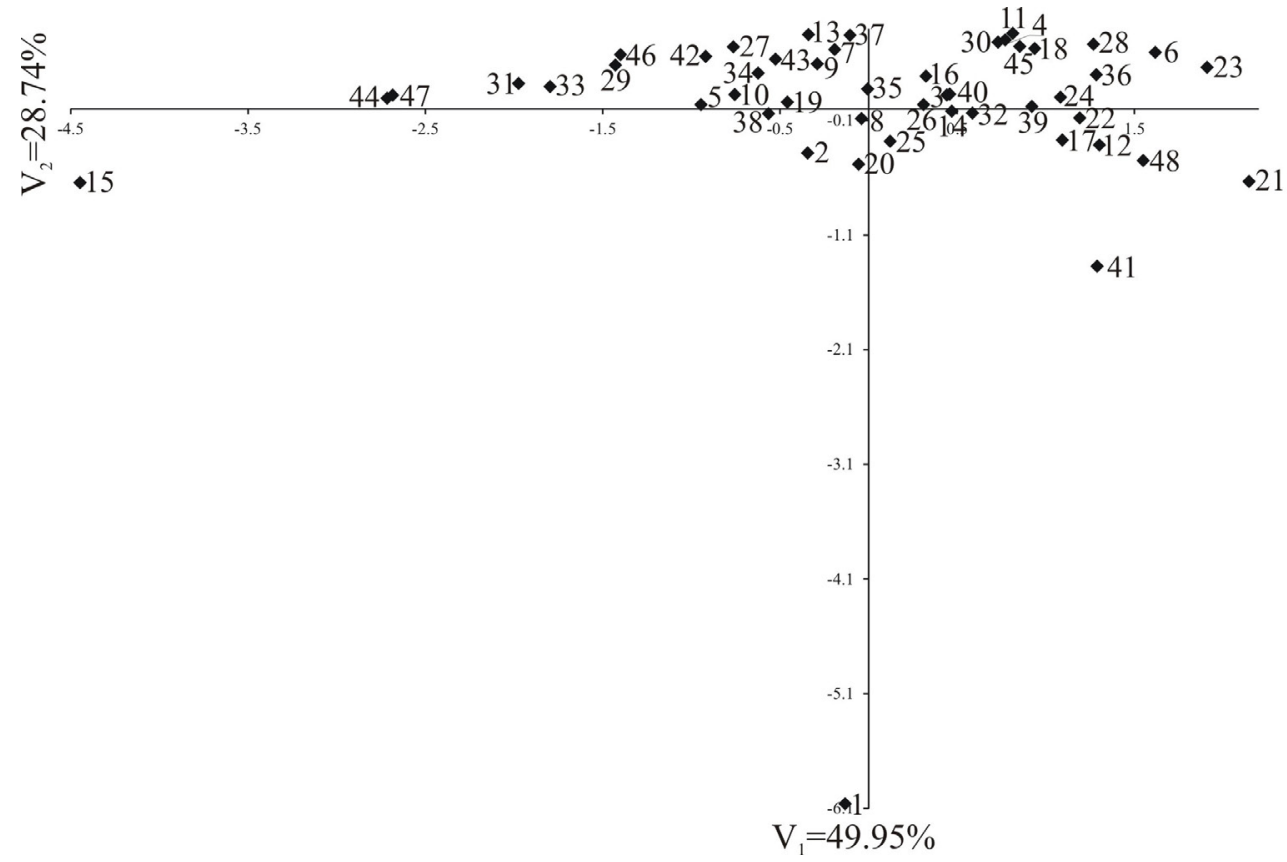

Fig. 2. Spatial distribution of chickpea accessions (Cicer arietinum L.) in terms of the first two canonical variables of static load parameters. See the accession number explanations in Table 1. 


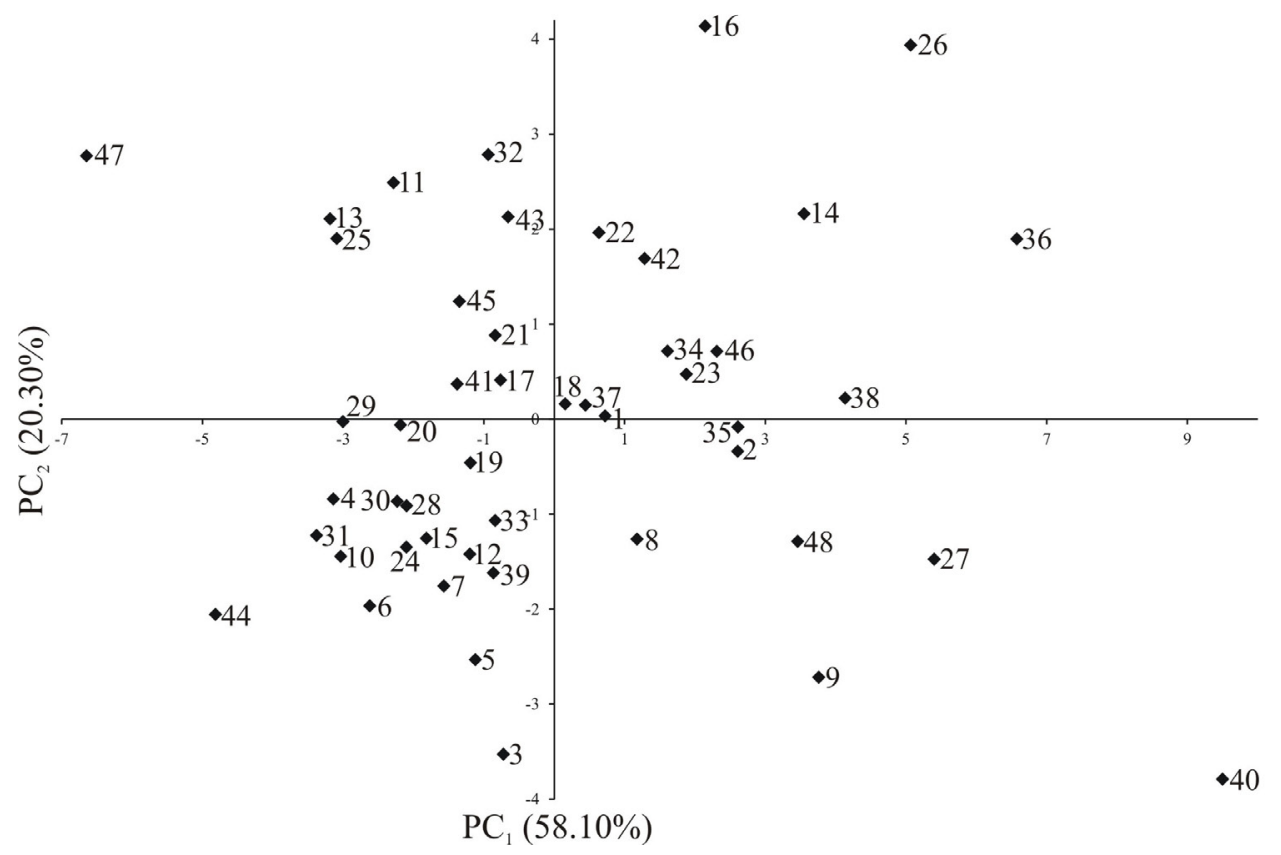

Fig. 3. Spatial distribution of chickpea accessions (Cicer arietinum L.) in terms of the two principal components of all the analysed traits of mechanical loads. See the accession number explanations in Table 1.

range from $6.4 \%$ for Desi type No. 44 (CAR 31) originating in Ethiopia to $13.7 \%$ for Kabuli type No. 26 (CAR 16) of Turkish origin. A similar range of fat content (3.8$10.9 \%$ ) was obtained by Singh (1985), while lower levels, i.e. 2.7-6.48 and 5.08-9.03\%, were found by Kaur et al. (2005) and Nobile et al. (2013), respectively. In the presented results, the average fat content was slightly higher in the Kabuli seed type (8.73\%), in comparison with the Desi type (7.89\%). Shah et al. (2013) observed higher fat content in the Desi seed type (5.7\%), as compared to Kabuli seeds $(4.5 \%)$.

The fat content, besides contributing to the energy needs, provides an essential supply of fatty acids for people (Shah et al., 2013). Data on the quantitative composition of selected fatty acids (palmitic, stearic, oleic, linoleic and linolenic) are summarised in Table 3 . The fatty acid profile of the chickpea accessions under analysis reveals that lipids are a good source of nutritionally essential linoleic and oleic acids. The linoleic acid was the dominating fatty acid, followed by oleic acid and palmitic acid, which is consistent with the results reported by De Falco et al. (2010) and Shah et al. (2013). The average content of omega-6 linoleic fatty acid is $61.0 \%$, ranging from $54.5 \%$ for Kabuli accession No. 40 (CAR 45 from Portugal, also characterised by the highest protein content), to $67.2 \%$ in Desi seed type No. 47 (CAR 43) originating in India. A similar mean content, at the level of $62.9 \%$, was observed by Baker et al. (1961), with the linoleic acid content ranging from 42.2 to $56.6 \%$ for the Kabuli type, and from 53.1 to $65.2 \%$ for the Desi accessions (Wang and Duan, 2004). Ranges of 54.7$56.2 \%$ and $49.4-68.4 \%$ were obtained for the Desi type by Zia-Ul-Haq et al. (2007) and Shah et al. (2013), respec- tively, and for the Kabuli seeds from 43.1 to $58.7 \%$ by Nobile et al. (2013). As mentioned above, omega-6 linoleic acid is the major fatty acid present in chickpea, followed by omega- 9 oleic acid (Table 3 ). The mean content of oleic acid in the seeds of the presented accessions is $23.1 \%$, and the obtained values varied from $18.9 \%$ in the seeds of Desi type No. 47 (CAR 43) of Indian origin to $29.8 \%$ for the seeds of the Kabuli type No. 40 (CAR 45) originating in Portugal, and also characterised by the highest protein content among all the accessions under analysis. Similar ranges for 25 mutants of chickpea (19.0-27.0\%) were observed by Shah et al. (2013). The mean value of oleic fatty acid for the Kabuli and Desi seeds at the level of 19.3\% was obtained by Baker et al. (1961), whereas the value of $31.6 \%$ was recorded for Kabuli seeds (Nobile et al., 2013), $21.9 \%$ for Desi seeds (Zia-Ul-Haq et al., 2007), and 32.6 and $22.3 \%$ for Kabuli and Desi seeds (Wang and Duan, 2004). These results, as well as the authors' own results (Table 3), indicate a higher content of oleic fatty acid in the Kabuli seeds, in comparison with the Desi seeds. The linolenic acid, which is an omega-3 fatty acid, is being studied for the ability to reduce the risk of heart diseases and cancer (Ofuya and Akhidue, 2005). The mean content of linolenic acid is $3.9 \%$, and the obtained results ranged from $3.0 \%$ for Kabuli accession No. 6 (CAR 60) of Russian origin to $5.3 \%$ for the seeds of accession No. 44 (CAR 31) originating in Ethiopia (Table 3). A similar average content of 3.3\% was observed by Baker et al. (1961), while the content of linolenic acid was higher in the Desi seeds (3.15\%), in comparison with the Kabuli seeds (2.69\%) (Wang and Duan, 2004). The results of the conducted analyses (Table 3) indicate that seeds of the presented accessions are rich in 
Table 3. Chemical composition of seeds of the investigated accessions, in terms of the protein and fat content, and the composition of fatty acids

\begin{tabular}{|c|c|c|c|c|c|c|c|c|c|c|}
\hline \multirow{2}{*}{ No. } & \multirow{2}{*}{$\begin{array}{l}\text { Accession } \\
\text { code }\end{array}$} & \multirow{2}{*}{$\begin{array}{l}\text { Country } \\
\text { of origin }\end{array}$} & \multirow{2}{*}{$\begin{array}{l}\text { Plant } \\
\text { type }\end{array}$} & \multirow{2}{*}{$\begin{array}{c}\text { Protein } \\
\text { content } \\
(\%)\end{array}$} & \multirow{2}{*}{$\begin{array}{c}\text { Fat } \\
\text { content } \\
(\%)\end{array}$} & \multicolumn{5}{|c|}{ Fatty acids composition* $(\%)$} \\
\hline & & & & & & $\mathrm{C}_{16: 0}$ & $\mathrm{C}_{18: 0}$ & $\mathrm{C}_{18: 1}$ & $\mathrm{C}_{18: 2}$ & $\mathrm{C}_{18: 3}$ \\
\hline 1 & CAR 18 & Poland & Kabuli & 13.9 & 7.8 & 9.6 & 2.1 & 23.8 & 60.4 & 4.1 \\
\hline 2 & CAR 46 & Russia & Kabuli & 13.6 & 7.6 & 10.0 & 2.2 & 25.2 & 59.0 & 3.5 \\
\hline 3 & CAR 47 & Russia & Kabuli & 18.0 & 7.2 & 9.4 & 1.4 & 24.0 & 61.8 & 3.3 \\
\hline 4 & CAR 58 & Russia & Desi & 15.9 & 7.6 & 10.5 & 2.1 & 21.1 & 63.1 & 3.3 \\
\hline 5 & CAR 59 & Russia & Kabuli & 17.4 & 7.7 & 9.8 & 2.4 & 22.9 & 61.7 & 3.2 \\
\hline 6 & CAR 60 & Russia & Kabuli & 17.4 & 8.0 & 10.0 & 2.6 & 21.6 & 62.8 & 3.0 \\
\hline 7 & CAR 48 & Slovakia & Kabuli & 16.3 & 7.3 & 10.6 & 2.2 & 21.8 & 61.2 & 4.2 \\
\hline 8 & CAR 49 & Slovakia & Kabuli & 16.4 & 9.8 & 10.6 & 1.6 & 24.1 & 60.5 & 3.2 \\
\hline 9 & CAR 50 & Slovakia & Kabuli & 16.2 & 8.0 & 10.0 & 1.8 & 26.6 & 58.4 & 3.2 \\
\hline 10 & CAR 51 & Slovakia & Kabuli & 15.9 & 6.6 & 10.4 & 1.8 & 21.0 & 62.3 & 4.5 \\
\hline 11 & CAR 52 & Slovakia & Kabuli & 12.9 & 9.4 & 10.4 & 1.7 & 20.7 & 62.6 & 4.6 \\
\hline 12 & CAR 29 & Czech & Kabuli & 15.4 & 6.7 & 9.8 & 1.7 & 22.8 & 61.5 & 4.2 \\
\hline 13 & CAR 30 & Czech & Kabuli & 12.2 & 7.2 & 10.5 & 1.8 & 20.9 & 63.4 & 3.4 \\
\hline 14 & CAR 68 & Czech & Kabuli & 12.9 & 11.4 & 9.8 & 2.4 & 25.1 & 59.3 & 3.3 \\
\hline 15 & CAR 65 & Czech & Desi & 15.9 & 7.6 & 10.9 & 1.7 & 21.4 & 61.3 & 4.7 \\
\hline 16 & CAR 19 & Albania & Kabuli & 12.0 & 12.7 & 9.8 & 3.2 & 22.8 & 59.8 & 4.4 \\
\hline 17 & CAR 20 & Albania & Kabuli & 14.1 & 8.0 & 10.3 & 2.9 & 22.3 & 61.3 & 3.2 \\
\hline 18 & CAR 21 & Albania & Desi & 13.8 & 7.7 & 9.7 & 1.7 & 23.6 & 61.0 & 4.0 \\
\hline 19 & CAR 22 & Albania & Kabuli & 15.7 & 8.6 & 9.6 & 3.0 & 22.1 & 61.7 & 3.6 \\
\hline 20 & CAR 23 & Albania & Desi & 14.3 & 7.0 & 9.9 & 1.6 & 22.0 & 62.6 & 4.0 \\
\hline 21 & CAR 24 & Bulgaria & Kabuli & 13.4 & 7.8 & 9.4 & 2.0 & 22.7 & 61.7 & 4.2 \\
\hline 22 & CAR 25 & Bulgaria & Kabuli & 13.1 & 9.3 & 9.3 & 5.2 & 22.2 & 60.0 & 3.3 \\
\hline 23 & CAR 26 & Bulgaria & Kabuli & 13.6 & 8.6 & 8.9 & 2.1 & 25.0 & 60.3 & 3.7 \\
\hline 24 & CAR 27 & Bulgaria & Kabuli & 15.9 & 7.2 & 9.8 & 1.6 & 22.3 & 62.5 & 3.8 \\
\hline 25 & CAR 15 & Turkey & Kabuli & 13.5 & 8.7 & 9.8 & 2.3 & 20.7 & 63.5 & 3.7 \\
\hline 26 & CAR 16 & Turkey & Kabuli & 11.9 & 13.7 & 9.2 & 2.4 & 26.0 & 59.1 & 3.4 \\
\hline 27 & CAR 80 & Turkey & Kabuli & 14.6 & 8.4 & 9.8 & 2.3 & 27.2 & 57.0 & 3.7 \\
\hline 28 & CAR 81 & Turkey & Kabuli & 15.7 & 7.7 & 9.7 & 1.4 & 22.1 & 62.5 & 4.3 \\
\hline 29 & CAR 82 & Turkey & Desi & 16.2 & 9.6 & 9.6 & 1.5 & 21.0 & 63.5 & 4.3 \\
\hline 30 & CAR 34 & Greece & Kabuli & 15.8 & 7.7 & 10.3 & 2.5 & 20.7 & 61.3 & 5.2 \\
\hline 31 & CAR 35 & Greece & Kabuli & 15.9 & 6.7 & 10.4 & 2.4 & 20.4 & 62.3 & 4.5 \\
\hline 32 & CAR 36 & Greece & Kabuli & 13.5 & 11.3 & 8.9 & 1.9 & 22.5 & 63.2 & 3.5 \\
\hline
\end{tabular}


Table 3. Continuation

\begin{tabular}{|c|c|c|c|c|c|c|c|c|c|c|}
\hline \multirow{2}{*}{ No. } & \multirow{2}{*}{$\begin{array}{l}\text { Accession } \\
\text { code }\end{array}$} & \multirow{2}{*}{$\begin{array}{l}\text { Country } \\
\text { of origin }\end{array}$} & \multirow{2}{*}{$\begin{array}{l}\text { Plant } \\
\text { type }\end{array}$} & \multirow{2}{*}{$\begin{array}{c}\text { Protein } \\
\text { content } \\
(\%)\end{array}$} & \multirow{2}{*}{$\begin{array}{c}\text { Fat } \\
\text { content } \\
(\%)\end{array}$} & \multicolumn{5}{|c|}{ Fatty acids composition* (\%) } \\
\hline & & & & & & $\mathrm{C}_{16: 0}$ & $\mathrm{C}_{18: 0}$ & $\mathrm{C}_{18: 1}$ & $\mathrm{C}_{18: 2}$ & $\mathrm{C}_{18: 3}$ \\
\hline 33 & CAR 37 & Greece & Desi & 15.0 & 6.9 & 9.7 & 1.6 & 23.1 & 61.4 & 4.3 \\
\hline 34 & CAR 38 & Greece & Desi & 13.0 & 8.2 & 10.4 & 1.9 & 24.1 & 59.7 & 4.0 \\
\hline 35 & CAR 53 & Italy & Kabuli & 14.0 & 8.6 & 10.0 & 2.6 & 24.9 & 59.1 & 3.4 \\
\hline 36 & CAR 54 & Italy & Kabuli & 12.5 & 11.7 & 9.5 & 2.5 & 27.5 & 57.4 & 3.1 \\
\hline 37 & CAR 55 & Italy & Kabuli & 13.8 & 7.8 & 10.4 & 2.2 & 23.5 & 60.6 & 3.3 \\
\hline 38 & CAR 56 & Italy & Kabuli & 13.5 & 9.2 & 10.0 & 2.1 & 25.9 & 58.1 & 3.9 \\
\hline 39 & CAR 57 & Italy & Kabuli & 16.0 & 7.5 & 10.3 & 1.7 & 23.0 & 61.5 & 3.5 \\
\hline 40 & CAR 45 & Portugal & Kabuli & 18.4 & 12.2 & 10.3 & 2.1 & 29.8 & 54.5 & 3.4 \\
\hline 41 & CAR 69 & Portugal & Kabuli & 14.9 & 8.9 & 8.7 & 1.9 & 23.1 & 63.2 & 3.1 \\
\hline 42 & CAR 39 & Spain & Kabuli & 12.0 & 8.2 & 10.2 & 2.0 & 24.0 & 60.3 & 3.5 \\
\hline 43 & CAR 70 & England & Kabuli & 12.4 & 8.5 & 9.5 & 2.4 & 22.1 & 61.3 & 4.7 \\
\hline 44 & CAR 31 & Ethiopia & Desi & 17.1 & 6.4 & 9.4 & 1.7 & 20.0 & 63.6 & 5.3 \\
\hline 45 & CAR 86 & Marocco & Desi & 14.2 & 9.6 & 10.0 & 1.6 & 22.0 & 62.4 & 4.0 \\
\hline 46 & CAR 67 & Australia & Desi & 11.8 & 6.7 & 11.4 & 2.1 & 22.7 & 56.6 & 7.2 \\
\hline 47 & CAR 43 & India & Desi & 14.1 & 9.5 & 8.6 & 1.6 & 18.9 & 67.2 & 3.7 \\
\hline 48 & CAR 113 & Cuba & Kabuli & 15.7 & 9.4 & 8.9 & 2.3 & 25.8 & 58.7 & 4.3 \\
\hline \multicolumn{3}{|c|}{ Means - Kabuli } & & 14.60 & 8.73 & 9.83 & 2.23 & 23.48 & 60.69 & 3.74 \\
\hline \multicolumn{3}{|c|}{ Means - Desi } & & 14.66 & 7.89 & 10.0 & 1.73 & 21.80 & 62.02 & 4.43 \\
\hline
\end{tabular}

*Palmitic acid $\left(\mathrm{C}_{16: 0}\right)$, stearic acid $\left(\mathrm{C}_{18: 0}\right)$, oleic acid $\left(\mathrm{C}_{18: 1}\right)$, linoleic acid $\left(\mathrm{C}_{18: 2}\right)$, linolenic acid $\left(\mathrm{C}_{18: 3}\right)$.

linoleic acids (both omega- 6 and omega-3), essential fatty acid, as well as oleic acid (omega-9). The total fat content in chickpea mainly consists of polyunsaturated (62-67\%) and mono-unsaturated (19-26\%) fatty acids. These results agree with our values which indicate that the analysed seeds consist, in average terms, in $64.9 \%$ of polyunsaturated fatty acids (PUFA) and in $23.1 \%$ of mono-unsaturated fatty acid (MUFA). Polyunsaturated essential fatty acids (18:3 omega-3 and 18:2 omega-6) are particularly important because they cannot be synthesised by human body and must be supplied through a properly-composed diet (Simopoulos 1999). Incorporating chickpeas into a healthy diet helps to increase the polyunsaturated fatty acids intake, which contributes to reducing the total cholesterol level in blood serum (Pittaway et al., 2008).

A low amount of saturated fatty acids (SFA) in chickpea is a natural endowment for deprived people (Shah et al., 2013). Among the analysed saturated fatty acids (palmitic and stearic acids) in chickpea seeds, the palmitic acid was found to prevail, with an average content of $9.87 \%$, and no visible differences were observed in terms of this acid between the Kabuli and Desi types. Among the investigated accession, the lowest content of palmitic acid $(8.6 \%)$ was found in the seeds of accession No. 47 (CAR 43) originating in India (also characterised by a high content of linoleic acid and a low content of oleic acid), and the highest content (11.4\%) in the seeds of accession No. 46 (CAR $67)$ of Australian origin. Similar ranges $(9.29-10.25 \%$ and 9.0-11.7\%) were obtained by Singhai and Shrivastava (2002), and by Nobile et al. (2013), respectively. No significant differences were also observed in terms of the palmitic acid content between the Kabuli $(9.41 \%)$ and Desi $(9.09 \%)$ seeds, in the ranges of $8.52-10.3 \%$ and $8.56-$ $11.0 \%$, respectively (Wang and Duan, 2012). As revealed by these authors, the content of saturated stearic acid (18:0) was slightly higher in the seeds of the Kabuli type (1.42\%), in comparison with the Desi type $(1.16 \%)$, in the ranges of 1.21-1.68 and $1.04-1.60 \%$, respectively. In the present 


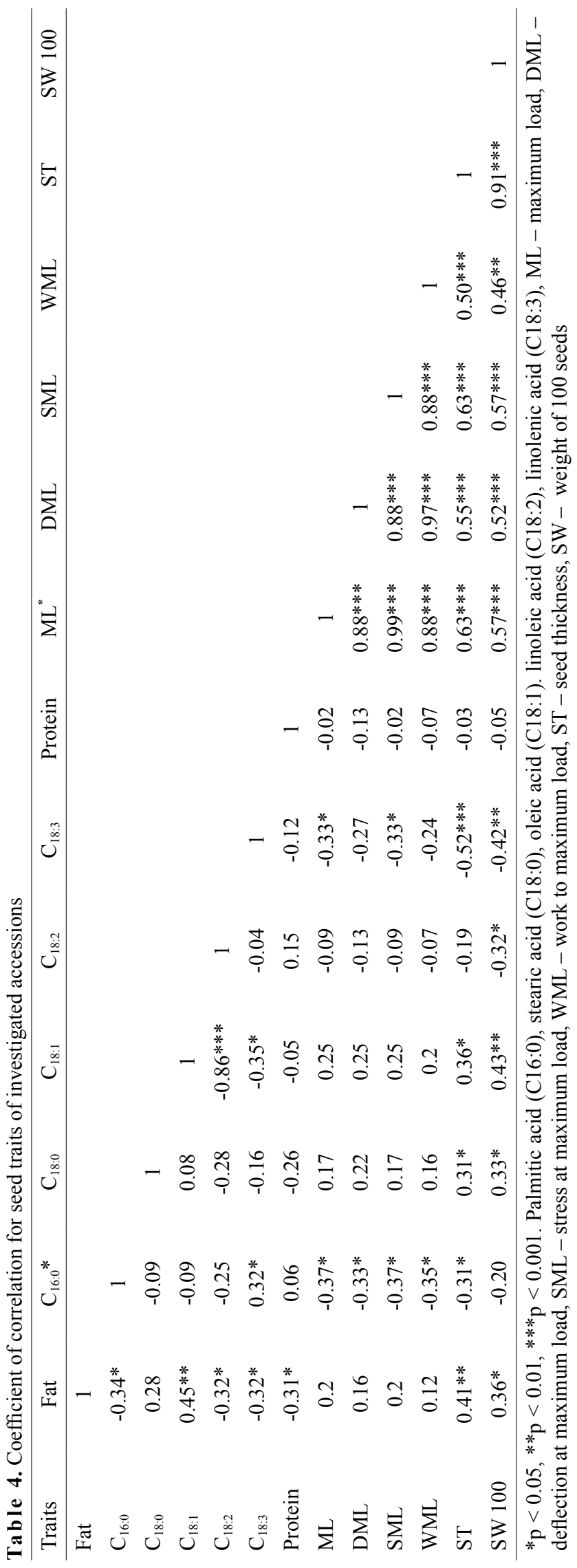

analysis, the seeds of the Kabuli type also contained more stearic fatty acid (2.23\%) than the seeds of the Desi type $(1.73 \%)$. The mean value of stearic acid was at the level of $2.12 \%$. To summarise the differences in the chemical composition of all the seeds, Fig. 4 features a spatial distribution of the obtained results. The spatial distribution of the chickpea accessions in terms of the first two principal components indicates a broad variation in the protein, fat and fatty acids content. Although the majority of the accessions under analysis are arranged in the central part of the plain, the differences in the distance between them indicate a varied degree of similarity in the responses of their seeds to chemical composition. The most extreme position in the bottom (accession No. 40) and upper (Nos 47, 16 and 26) part of the plane is characteristic of the lowest similarity to other accessions. It is particularly true for the seeds of Kabuli accession No. 40 (CAR 45) originating in Portugal, characterised by the highest protein content, a high fat content and, in terms of fatty acids, the highest content of oleic acids and the lowest content of linoleic acid.

Some of the chickpea types are closely associated among themselves (Ali et al., 2011; Akhtar et al., 2011). The simple correlation coefficients calculated for the chickpea types examined are given in Table 4. Strong and significant correlations were observed between individual mechanical parameters. Apart from the correlation between all four mechanical parameters, seed thickness as well as 100 seeds weight were significantly positively correlated with this parameter, which indicates a close relationship between seed resistance to mechanical loads and seed size. A similar effect was reported by Rybiński et al. (2009) for selected species of pulse crops. In respect of the chemical composition of seeds, the fat content was positively correlated with the content of oleic acid. Significant negative correlations were determined between the fat content and the content of palmitic, linoleic and linolenic acid. Among the fatty acids under analysis, the highest negative correlation was found between oleic acid and linoleic acid. A very high correlation between these fatty acids in the seeds of common vetch was reported by Rybiński et al. (2015). Another unsaturated fatty acid, i.e. linolenic acid, was negatively correlated with oleic acid and positively with palmitic acid. The protein content revealed a significant (and negative) correlation only with the fat content. Moreover, the fat content was positively correlated with seed thickness and the weight of 100 seeds. No significant correlation was observed between biochemical traits and the four mechanical parameters examined, with an exception of a significant negative correlation between palmitic acid and linolenic acid, and the maximum load (ML) and stress of the maximum load (SML). Other traits, i.e. seeds thickness and 100 seed weight, were positively correlated with the fat content but no such associations were observed 


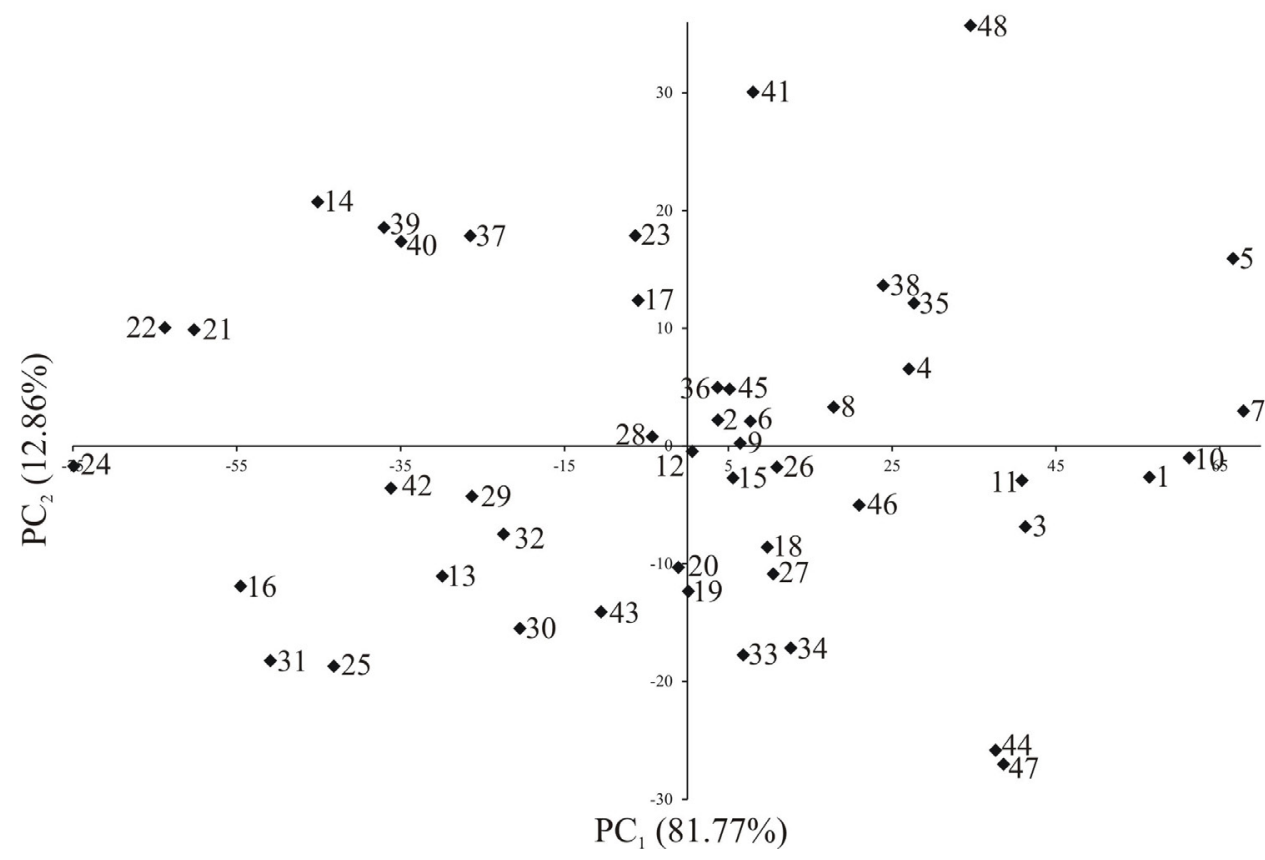

Fig. 4. Spatial distribution of chickpea accessions (Cicer arietinum L.) in terms of the two principal components in the chemical composition of all the seeds. See the accession number explanations in Table 1.

with the protein content. Moreover, significant negative or positive associations were determined between seed thickness and 100 seed weight, and fatty acids.

\section{CONCLUSIONS}

1. The results obtained indicated a broad range of trait variations, based on field observations and laboratory analyses of the resistance of seeds to mechanical loads and their chemical composition. It can be concluded that the accessions derived from Gene Banks may constitute a rich source of trait variability, which could be used both for scientific and cultivation purposes.

2. No significant correlation was observed between biochemical traits and mechanical parameters, except for the negative significant correlation between palmitic acid and linolenic acid, and the maximum load and stress of the maximum load.

Conflict of interest: The authors declare they have no conflict of interest.

\section{REFERENCES}

Abbo S., Shienberg D., Lichtenzveig J., Lev Jadun S., and Gopher A., 2003. The chickpea, summer cropping and new model for pulse domestication in the ancient Near East. Quarterly Review Biology, 78, 435-448.

Akhtar L.H., Pervez M.A., and Nasim M., 2011. Genetic divergence and inter-relationship studies in chickpea (Cicer arietinum L.). Pakistan J. Agric. Sci., 48, 35-39.

Ali Q., Tahir M.H.N., Sadaqat H.A., Arshad S., Farooq J., Ahsan M., Waseem M., and Iqbal A., 2011. Genetic va- riability and correlation analysis for quantitative traits in chickpea genotypes (Cicer arietinum L.). J. Bacteriology, 3, 6-9.

Baker H.E., Papaconstantinou J.A. and Cross C.K., 1961. Protein and lipid constitution of Pakistan pulses. J. Sci. Food Agric., 12, 205-207.

De Almeida Costa G.E., De Silva Queiroz-Monici K., Pissini Machado Reis S., and Costa De Oliveira A., 2006. Chemical composition. dietary fibre and resistant starch contents of raw and cooked pea, common bean, chickpea and lentil legume. Food Chemistry, 94, 327-330.

De Falco E., Imperato R., Landi G., Nicolais Vpicinelli A.L., and Rastrelli L., 2010. Nutritional characterization of Cicer arietinum L. cultivars with respect to morphological and agronomic parameters. Emirates J. Food Agric., 22, 377-387.

Frimpong A., Sinha A., and Tar'an B., 2009. Genotype and growing environment influence chickpea (Cicer arietinum L.) seed composition. J. Sci. Food Agric., 89, 2052-2063.

Jukanti A.K., Gaur P.M., Gowda C.L.L., and Chibbar R.N. 2012. Nutritional quality and health benefits of chickpea (Cicer arietinum L.): a review. British J. Nutrition, 108, 11-26.

Kaur M., Singh N., and Sodhi N.S., 2005. Physicochemical, cooking, textural and roasting characteristics of chickpea (Cicer arietinum L.) cultivars. J. Food Eng., 69, 511-517.

Kozak M., Bocianowski J., and Rybiński W. 2013. Note on the use of coefficient of variation for data from agricultural factorial experiments. Bulgarian J. Agric. Sci., 19, 644-646.

Nobile C.G.M., Carreras J., Grosso R., Inga M., Silva M., Aguilar R., Allende M.J., Badini R., and Martinez M.J., 2013. Proximate composition and seed lipid components of "kabuli"-type chickpea (Cicer arietinum L.) from Argentina. J. Agric. Sci., 4, 729-737. 
Ofuya Z.M. and Akhidue V. 2005. The role of pulses in human nutrition. A review. J. Appl. Sci. Environ. Manag., 9, 99-104.

Pittaway J.K., Robertson I.K., and Ball M.J., 2008. Chickpea may influence fatty acid and fiber intake in an ad libitum diet. leading to small improvement in serum lipid profile and glycemic control. J. American Dietetic Association, 108, 1009-1013.

Ramanappa T.M., Chandrashshekara K., and Duthan D., 2013. Analysis of variability for economically important traits in chickpea (Cicer arietinum L.). Int. J. Res.Applied, Natural Social Sci., 1, 133-140.

Rybiński W., Banda M., Bocianowski J., Borner A., Starzycki M., and Szot B., 2015. Estimation of mechanical properties of seeds of common vetch accessions (Vicia sativa L.). Genetic Resources and Crop Evolution, 62, 361-375.

Rybiński W., Rusinek R., Szot B., Bocianowski J., and Starzycki M., 2014. Analysis of interspecies physicochemical variation of grain legumes seeds. Int. Agrophys., 28, 491-500.

Rybiński W., Szot B., and Pokora L., 2004. Estimation of genetic variation and physical properties of seeds for grass pea mutants (Lathyrus sativus L.). Int. Agrophysics, 18, 339-346.

Rybiński W., Szot B., and Rusinek R., 2008. Estimation of morphological and mechanical properties of grasspea seeds (Lathyrus sativus L.) originating from EU countries. Int. Agrophysics, 22, 261-227.

Rybiński W., Szot B., Rusinek R., and Bocianowski J., 2009. Estimation of geometric and mechanical properties of seeds Polish cultivars and lines representing selected species of pulse crop. Int. Agrophys., 23, 257-267.
Shah T.M., Iqbal Z., Rafique M. and Atta B.M., 2013. Induced genetic variability for fatty acids and oil contents in chickpea (Cicer arietinum L.). Int. J. Agric. Biol., 15, 419-426.

Shapiro S.S. and Wilk M.B., 1965. An analysis of variance test for normality (complete samples). Biometrika, 52, 591-611.

Şehirali S., 1988. Cereal Grains. Ankara University, Faculty of Agriculture Publications: 1089, Textbook: 314, Ankara, Turkey.

Simopoulos A., 1999. Essential fatty acids in health and chronic disease. American J. Clinical Nutrition, 70, 560-569.

Singh U., 1985. Nutritional quality of chickpea (Cicer arietinum L.): current status and future research needs. Plant Foods Human Nutrition, 35, 339-351.

Singhai B. and Shrivastava S.K., 2002. Studies on fatty acid composition of seed of improved varieties of Cicer arietinum. Asian J. Chemistry, 14, 1080-1082.

Upadhyaya H.D., 2003. Geographical patterns of variation for morphological and agronomic characteristics in the chickpea germplasm collection. Euphytica, 132, 343-352.

Wang N. and Daun J.K., 2004. The chemical composition and nutritive value of Canadian pulses. In: Canadian Grain Commission Report, pp.19-29.

Yucel D.O., Anlarsal A.E., and Yucel C., 2006. Genetic variability. correlation and path analysis of yield. and yield components in chickpea (Cicer arietinum L.). Turkish J. Agric. Forestry, 30, 183-188.

Zia-Ul-Haq M., Iqbal S., and Ahmad S., 2007. Nutritional and compositional study of desi chickpea (Cicer arietinum L.) cultivars grown in Punjab, Pakistan. Food Chemistry, 105, 1357-1363. 